\title{
Global temperature change
}

\author{
James Hansen*t‡, Makiko Sato*†, Reto Ruedy*§, Ken Lo*§, David W. Leaף, and Martin Medina-Elizadeף \\ *National Aeronautics and Space Administration Goddard Institute for Space Studies, ${ }^{\dagger}$ Columbia University Earth Institute, and §Sigma Space Partners, Inc., \\ 2880 Broadway, New York, NY 10025; and "Department of Earth Science, University of California, Santa Barbara, CA 93106
}

Contributed by James Hansen, July 31, 2006

Global surface temperature has increased $\approx 0.2^{\circ} \mathrm{C}$ per decade in the past 30 years, similar to the warming rate predicted in the $1980 \mathrm{~s}$ in initial global climate model simulations with transient greenhouse gas changes. Warming is larger in the Western Equatorial Pacific than in the Eastern Equatorial Pacific over the past century, and we suggest that the increased West-East temperature gradient may have increased the likelihood of strong El Niños, such as those of 1983 and 1998. Comparison of measured sea surface temperatures in the Western Pacific with paleoclimate data suggests that this critical ocean region, and probably the planet as a whole, is approximately as warm now as at the Holocene maximum and within $\approx 1^{\circ} \mathrm{C}$ of the maximum temperature of the past million years. We conclude that global warming of more than $\approx 1^{\circ} \mathrm{C}$, relative to 2000, will constitute "dangerous" climate change as judged from likely effects on sea level and extermination of species.

climate change | El Niños | global warming | sea level | species extinctions

G lobal temperature is a popular metric for summarizing the state of global climate. Climate effects are felt locally, but the global distribution of climate response to many global climate forcings is reasonably congruent in climate models (1), suggesting that the global metric is surprisingly useful. We will argue further, consistent with earlier discussion $(2,3)$, that measurements in the Western Pacific and Indian Oceans provide a good indication of global temperature change.

We first update our analysis of surface temperature change based on instrumental data and compare observed temperature change with predictions of global climate change made in the 1980s. We then examine current temperature anomalies in the tropical Pacific Ocean and discuss their possible significance. Finally, we compare paleoclimate and recent data, using the Earth's history to estimate the magnitude of global warming that is likely to constitute dangerous human-made climate change.

\section{Modern Global Temperature Change}

Global surface temperature in more than a century of instrumental data is recorded in the Goddard Institute for Space Studies analysis for 2005. Our analysis, summarized in Fig. 1, uses documented procedures for data over land (4), satellite measurements of sea surface temperature (SST) since 1982 (5), and a ship-based analysis for earlier years (6). Estimated $2 \sigma$ error ( $95 \%$ confidence) in comparing nearby years of global temperature (Fig. $1 A$ ), such as 1998 and 2005 , decreases from $0.1^{\circ} \mathrm{C}$ at the beginning of the 20th century to $0.05^{\circ} \mathrm{C}$ in recent decades (4). Error sources include incomplete station coverage, quantified by sampling a modelgenerated data set with realistic variability at actual station locations (7), and partly subjective estimates of data quality problems (8). The estimated uncertainty of global mean temperature implies that we can only state that 2005 was probably the warmest year.

The map of temperature anomalies for the first half-decade of the 21st century (Fig. 1B), relative to 1951-1980 climatology, shows that current warmth is nearly ubiquitous, generally larger over land than over ocean, and largest at high latitudes in the Northern Hemisphere. Our ranking of 2005 as the warmest year depends on the positive polar anomalies, especially the unusual Arctic warmth. In calculating the global mean, we give full weight to all regions based on area. Meteorological stations are sparse in the Arctic, but the estimated strong warm anomaly there in 2005 is consistent with record low sea ice concentration and Arctic temperature anomalies inferred from infrared satellite data (9).

Our analysis includes estimated temperature anomalies up to $1,200 \mathrm{~km}$ from the nearest measurement station (7). Resulting spatial extrapolations and interpolations of temperature anomalies usually are meaningful for seasonal and longer time scales at middle and high latitudes, where the spatial scale of anomalies is set by Rossby waves (7). Thus, we believe that the unusual Arctic warmth of 2005 is real. Other characteristics of our analysis method are summarized in Supporting Text, which is published as supporting information on the PNAS web site.

Independent analysis by the National Climate Data Center (www.ncdc.noaa.gov/oa/climate/research/2005/ann/global. html), using a "teleconnection" approach to fill in data sparse regions, also finds 2005 to be the warmest year. The joint analysis of the University of East Anglia and the Hadley Centre (www.met-office.gov.uk/research/hadleycentre/ obsdata/globaltemperature.html) also yields high global temperature for 2005, but a few hundredths of a degree cooler than in 1998.

Record, or near record, warmth in 2005 is notable, because global temperature did not receive a boost from an El Niño in 2005. The temperature in 1998 , on the contrary, was lifted $0.2^{\circ} \mathrm{C}$ above the trend line by a "super El Niño" (see below), the strongest El Niño of the past century.

Global warming is now $0.6^{\circ} \mathrm{C}$ in the past three decades and $0.8^{\circ} \mathrm{C}$ in the past century. It is no longer correct to say "most global warming occurred before 1940." A better summary is: slow global warming, with large fluctuations, over the century up to 1975 , followed by rapid warming at a rate $\approx 0.2^{\circ} \mathrm{C}$ per decade. Global warming was $\approx 0.7^{\circ} \mathrm{C}$ between the late 19 th century (the earliest time at which global mean temperature can be accurately defined) and 2000, and continued warming in the first half decade of the 21st century is consistent with the recent rate of $+0.2^{\circ} \mathrm{C}$ per decade.

The conclusion that global warming is a real climate change, not an artifact due to measurements in urban areas, is confirmed by surface temperature change inferred from borehole temperature profiles at remote locations, the rate of retreat of alpine glaciers around the world, and progressively earlier breakup of ice on rivers and lakes (10). The geographical distribution of warming (Fig. 1B) provides further proof of real climate change. Largest warming is in remote regions including high latitudes. Warming occurs over ocean areas, far from direct human effects, with warming over ocean less than over land, an expected result for a forced climate change because of the ocean's great thermal inertia.

Early Climate Change Predictions. Manabe and Wetherald (11) made the first global climate model (GCM) calculations of warming due

\footnotetext{
Author contributions: D.W.L. and M.M.-E. contributed data; J.H., M.S., R.R., K.L., D.W.L. and M.M.-E. analyzed data; and J.H. wrote the paper.

The authors declare no conflict of interest.

Freely available online through the PNAS open access option.

Abbreviations: SST, sea surface temperature; GHG, greenhouse gas; EEP, Eastern Equatoria Pacific; WEP, Western Equatorial Pacific; DAI, dangerous antrhopogenic interference; BAU, business as usual; AS, alternative scenario; BC, black carbon.

\#To whom correspondence should be addressed: E-mail: jhansen@giss.nasa.gov.

C 2006 by The National Academy of Sciences of the USA
} 


\section{A Global Land-Ocean Temperature Anomaly $\left({ }^{\circ} \mathrm{C}\right) \quad$ B 2001-2005 Mean Surface Temperature Anomaly $\left({ }^{\circ} \mathrm{C}\right)$}

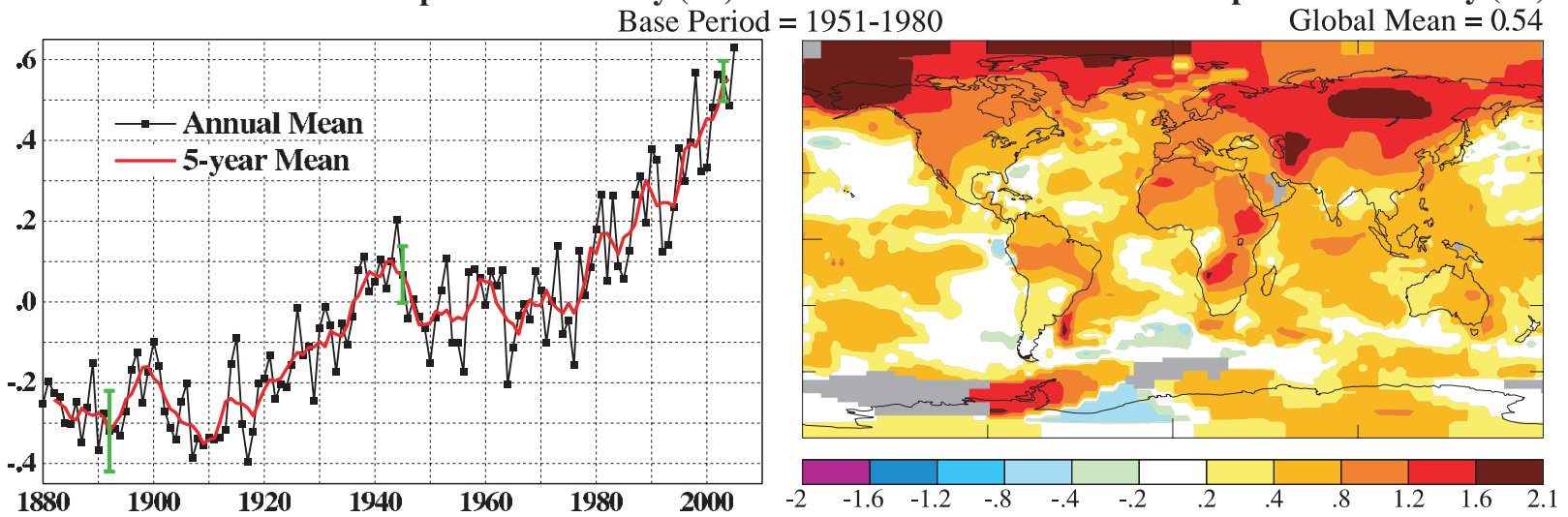

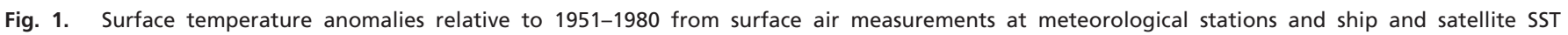
measurements. (A) Global annual mean anomalies. (B) Temperature anomaly for the first half decade of the 21 st century.

to instant doubling of atmospheric $\mathrm{CO}_{2}$. The first GCM calculations with transient greenhouse gas (GHG) amounts, allowing comparison with observations, were those of Hansen et al. (12). It has been asserted that these calculations, presented in congressional testimony in 1988 (13), turned out to be "wrong by 300\%" (14). That assertion, posited in a popular novel, warrants assessment because the author's views on global warming have been welcomed in testimony to the United States Senate (15) and in a meeting with the President of the United States (16), at a time when the Earth may be nearing a point of dangerous human-made interference with climate (17).

The congressional testimony in 1988 (13) included a graph (Fig. 2) of simulated global temperature for three scenarios (A, B, and C) and maps of simulated temperature change for scenario B. The three scenarios were used to bracket likely possibilities. Scenario A was described as "on the high side of reality," because it assumed rapid exponential growth of GHGs and it included no large volcanic eruptions during the next half century. Scenario $C$ was described as "a more drastic curtailment of emissions than has generally been imagined," specifically GHGs were assumed to stop increasing after 2000. Intermediate scenario B was described as "the most plausible." Scenario B has continued moderate increase in the rate of GHG emissions and includes three large volcanic eruptions sprin-

Annual Mean Global Temperature Change: $\Delta \mathbf{T}_{\mathrm{S}}\left({ }^{\circ} \mathrm{C}\right)$

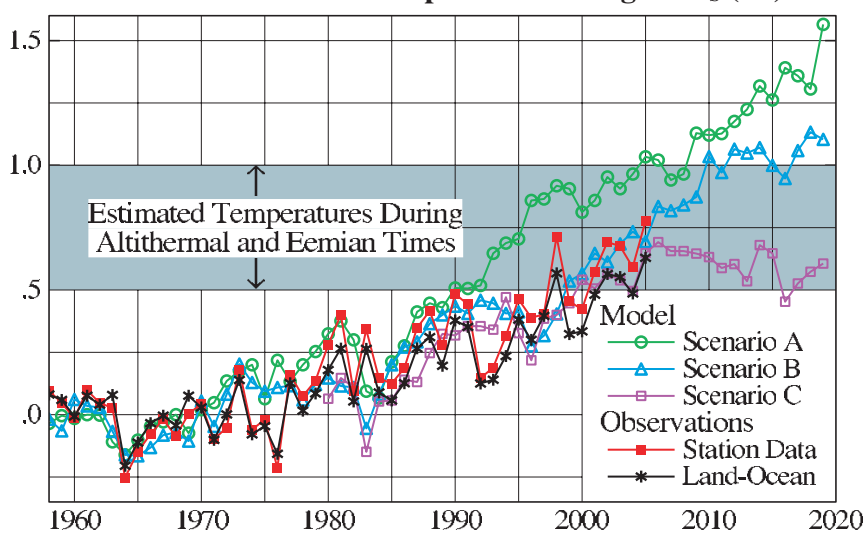

Fig. 2. Global surface temperature computed for scenarios $A, B$, and $C$ (12), compared with two analyses of observational data. The $0.5^{\circ} \mathrm{C}$ and $1{ }^{\circ} \mathrm{C}$ temperature levels, relative to 1951-1980, were estimated (12) to be maximum global temperatures in the Holocene and the prior interglacial period, respectively. kled through the 50-year period after 1988 , one of them in the 1990s.

Real-world GHG climate forcing (17) so far has followed a course closest to scenario B. The real world even had one large volcanic eruption in the 1990s, Mount Pinatubo in 1991, whereas scenario B placed a volcano in 1995.

Fig. 2 compares simulations and observations. The red curve, as in ref. 12, is the updated Goddard Institute for Space Studies observational analysis based on meteorological stations. The black curve is the land-ocean global temperature index from Fig. 1, which uses SST changes for ocean areas $(5,6)$. The land-ocean temperature has more complete coverage of ocean areas and yields slightly smaller long-term temperature change, because warming on average is less over ocean than over land (Fig. $1 B$ ).

Temperature change from climate models, including that reported in 1988 (12), usually refers to temperature of surface air over both land and ocean. Surface air temperature change in a warming climate is slightly larger than the SST change (4), especially in regions of sea ice. Therefore, the best temperature observation for comparison with climate models probably falls between the meteorological station surface air analysis and the land-ocean temperature index.

Observed warming (Fig. 2) is comparable to that simulated for scenarios B and C, and smaller than that for scenario A. Following refs. 18 and 14, let us assess "predictions" by comparing simulated and observed temperature change from 1988 to the most recent year. Modeled 1988-2005 temperature changes are 0.59, 0.33, and $0.40^{\circ} \mathrm{C}$, respectively, for scenarios A, B, and C. Observed temperature change is $0.32^{\circ} \mathrm{C}$ and $0.36^{\circ} \mathrm{C}$ for the land-ocean index and meteorological station analyses, respectively.

Warming rates in the model are $0.35,0.19$, and $0.24^{\circ} \mathrm{C}$ per decade for scenarios A, B. and C, and 0.19 and $0.21^{\circ} \mathrm{C}$ per decade for the observational analyses. Forcings in scenarios $\mathrm{B}$ and $\mathrm{C}$ are nearly the same up to 2000, so the different responses provide one measure of unforced variability in the model. Because of this chaotic variability, a 17-year period is too brief for precise assessment of model predictions, but distinction among scenarios and comparison with the real world will become clearer within a decade.

Close agreement of observed temperature change with simulations for the most realistic climate forcing (scenario B) is accidental, given the large unforced variability in both model and real world. Indeed, moderate overestimate of global warming is likely because the sensitivity of the model used $(12), 4.2^{\circ} \mathrm{C}$ for doubled $\mathrm{CO}_{2}$, is larger than our current estimate for actual climate sensitivity, which is $3 \pm 1^{\circ} \mathrm{C}$ for doubled $\mathrm{CO}_{2}$, based mainly on paleoclimate data (17). More complete analyses should include other climate forcings and 
A SST Change $\left({ }^{\circ} \mathrm{C}\right)$ from $1870-1900$ to $2001-2005$

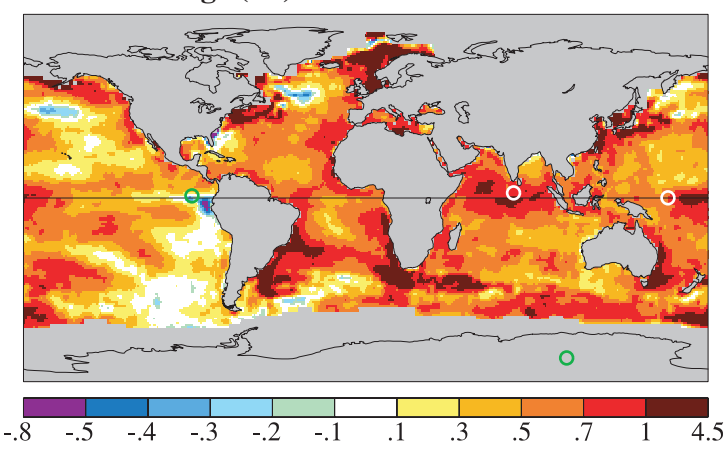

B Western and Eastern Pacific Temperature Anomalies $\left({ }^{\circ} \mathrm{C}\right)$

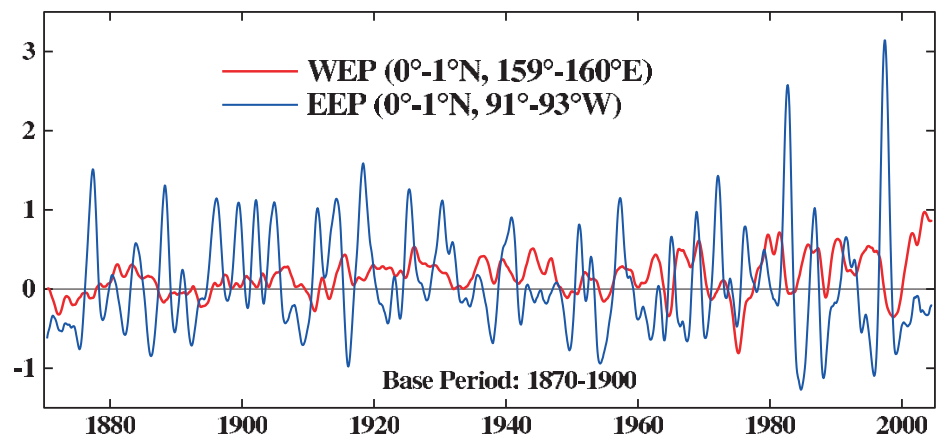

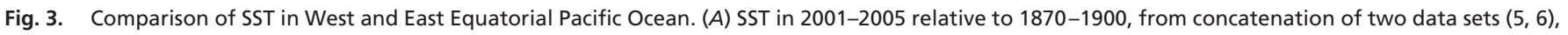
as described in the text. $(B)$ SSTs (12-month running means) in WEP and EEP relative to 1870-1900 means.

cover longer periods. Nevertheless, it is apparent that the first transient climate simulations (12) proved to be quite accurate, certainly not "wrong by $300 \%$ " (14). The assertion of $300 \%$ error may have been based on an earlier arbitrary comparison of 19881997 observed temperature change with only scenario A (18). Observed warming was slight in that 9-year period, which is too brief for meaningful comparison.

Super El Niños. The 1983 and 1998 El Niños were successively labeled "El Niño of the century," because the warming in the Eastern Equatorial Pacific (EEP) was unprecedented in 100 years (Fig. 3). We suggest that warming of the Western Equatorial Pacific (WEP), and the absence of comparable warming in the EEP, has increased the likelihood of such "super El Niños."

In the "normal" (La Niña) phase of El Niño Southern Oscillation the east-to-west trade winds push warm equatorial surface water to the west such that the warmest SSTs are located in the WEP near Indonesia. In this normal state, the thermocline is shallow in the EEP, where upwelling of cold deep water occurs, and deep in the WEP (figure 2 of ref. 20). Associated with this tropical SST gradient is a longitudinal circulation pattern in the atmosphere, the Walker cell, with rising air and heavy rainfall in the WEP and sinking air and drier conditions in the EEP. The Walker circulation enhances upwelling of cold water in the East Pacific, causing a powerful positive feedback, the Bjerknes (21) feedback, which tends to maintain the La Niña phase, as the SST gradient and resulting higher pressure in the EEP support east-to-west trade winds.

This normal state is occasionally upset when, by chance, the east-to-west trade winds slacken, allowing warm water piled up in the west to slosh back toward South America. If the fluctuation is large enough, the Walker circulation breaks down and the Bjerknes feedback loses power. As the east-to-west winds weaken, the Bjerknes feedback works in reverse, and warm waters move more strongly toward South America, reducing the thermocline tilt and cutting off upwelling of cold water along the South American coast. In this way, a classical El Niño is born.

Theory does not provide a clear answer about the effect of global warming on El Niños $(19,20)$. Most climate models yield either a tendency toward a more El Niño-like state or no clear change (22). It has been hypothesized that, during the early Pliocene, when the Earth was $3^{\circ} \mathrm{C}$ warmer than today, a permanent El Niño condition existed (23).

We suggest, on empirical grounds, that a near-term global warming effect is an increased likelihood of strong El Niños. Fig. $1 B$ shows an absence of warming in recent years relative to 1951-1980 in the equatorial upwelling region off the coast of South America. This is also true relative to the earliest period of SST data, 1870-1900 (Fig. 3A). Fig. 7, which is published as supporting information on the PNAS web site, finds a similar result for linear trends of SSTs. The trend of temperature minima in the East Pacific, more relevant for our purpose, also shows no equatorial warming in the East Pacific.

The absence of warming in the EEP suggests that upwelling water there is not yet affected much by global warming. Warming in the WEP, on the other hand, is $0.5-1^{\circ} \mathrm{C}$ (Fig. 3). We suggest that increased temperature difference between the near-equatorial WEP and EEP allows the possibility of increased temperature swing from a La Niña phase to El Niño, and that this is a consequence of global warming affecting the WEP surface sooner than it affects the deeper ocean.

Fig. $3 B$ compares SST anomalies (12-month running means) in the WEP and EEP at sites (marked by circles in Fig. $3 A$ ) of paleoclimate data discussed below. Absolute temperatures at these sites are provided in Fig. 8, which is published as supporting information on the PNAS web site. Even though these sites do not have the largest warming in the WEP or largest cooling in the EEP, Fig. $3 B$ reveals warming of the WEP relative to the EEP [135-year changes, based on linear trends, are $+0.27^{\circ} \mathrm{C}(\mathrm{WEP})$ and $-0.01^{\circ} \mathrm{C}$ (EEP)].

The 1983 and 1998 El Niños in Fig. 3B are notably stronger than earlier El Niños. This may be partly an artifact of sparse early data or the location of data sites, e.g., the late $1870 \mathrm{~s} \mathrm{El} \mathrm{Niño} \mathrm{is} \mathrm{relatively}$ stronger if averages are taken over Niño 3 or a $5^{\circ} \times 10^{\circ}$ box. Nevertheless, "super El Niños" clearly were more abundant in the last quarter of the 20th century than earlier in the century.

Global warming is expected to slow the mean tropical circulation (24-26), including the Walker cell. Sea level pressure data suggest a slowdown of the longitudinal wind by $\approx 3.5 \%$ in the past century (26). A relaxed longitudinal wind should reduce the WEP-EEP temperature difference on the broad latitudinal scale $\left(\approx 10^{\circ} \mathrm{N}\right.$ to $15^{\circ} \mathrm{S}$ ) of the atmospheric Walker cell. Observed SST anomalies are consistent with this expectation, because the cooling in the EEP relative to WEP decreases at latitudes away from the narrower region strongly affected by upwelling off the coast of Peru (Fig. $3 A$ ). Averaged over $10^{\circ} \mathrm{N}$ to $15^{\circ} \mathrm{S}$, observed warming is as great in the EEP as in the WEP (see also Fig. 7).

We make no suggestion about changes of El Niño frequency, and we note that an abnormally warm WEP does not assure a strong El Niño. The origin and nature of El Niños is affected by chaotic ocean and atmosphere variations, the season of the driving anomaly, the state of the thermocline, and other factors, assuring that there will always be great variability of strength among El Niños.

Will increased contrast between near-equatorial WEP and EEP SSTs be maintained or even increase with more global warming? The WEP should respond relatively rapidly to increasing GHGs. In the EEP, to the extent that upwelling water has not been exposed to the surface in recent decades, little warming is expected, and the 
A Western Pacific SST $\left({ }^{\circ} \mathrm{C}\right)$

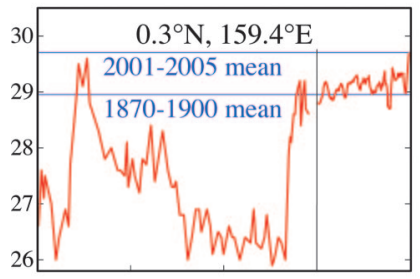

B Eastern Pacific SST $\left({ }^{\circ} \mathrm{C}\right)$

C Indian Ocean SST $\left({ }^{\circ} \mathrm{C}\right)$

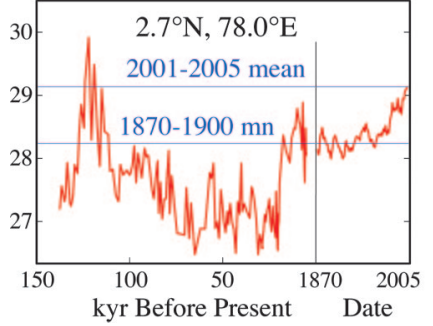

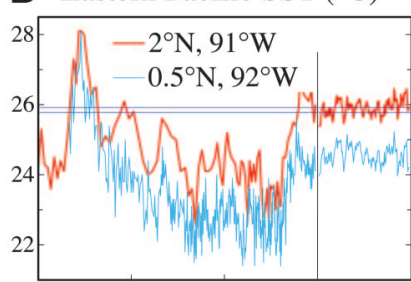

D Vostok Temperature $\left({ }^{\circ} \mathrm{C}\right)$

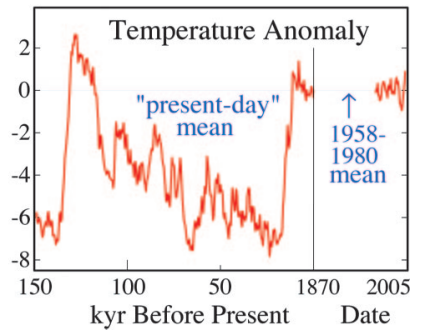

Fig. 4. Comparison of modern surface temperature measurements with paleoclimate proxy data in the $\operatorname{WEP}(28)(A), \operatorname{EEP}(3,30,31)(B)$, Indian Ocean $(40)(C)$, and Vostok Antarctica (41) (D).

contrast between WEP and EEP may remain large or increase in coming decades.

Thus, we suggest that the global warming effect on El Niños is analogous to an inferred global warming effect on tropical storms (27). The effect on frequency of either phenomenon is unclear, depending on many factors, but the intensity of the most powerful events is likely to increase as GHGs increase. In this case, slowing the growth rate of GHGs should diminish the probability of both super El Niños and the most intense tropical storms.

\section{Estimating Dangerous Climate Change}

Modern vs. Paleo Temperatures. Modern SST measurements $(5,6)$ are compared with proxy paleoclimate temperature (28) in the WEP (Ocean Drilling Program Hole 806B, $0^{\circ} 19^{\prime} \mathrm{N}, 159^{\circ} 22^{\prime} \mathrm{E}$; site circled in Fig. $3 A$ ) in Fig. $4 A$. Modern data are from ships and buoys for 1870-1981 (6) and later from satellites (5). In concatenation of satellite and ship data, as shown in Fig. $8 A$, the satellite data are adjusted down slightly so that the 1982-1992 mean matches the mean ship data for that period.

The paleoclimate SST, based on $\mathrm{Mg}$ content of foraminifera shells, provides accuracy to $\approx 1^{\circ} \mathrm{C}(29)$. Thus we cannot be sure that we have precisely aligned the paleo and modern temperature scales. Accepting paleo and modern temperatures at face value implies a WEP 1870 SST in the middle of its Holocene range. Shifting the scale to align the 1870 SST with the lowest Holocene value raises the paleo curve by $\approx 0.5^{\circ} \mathrm{C}$. Even in that case, the 2001-2005 WEP

SST is at least as great as any Holocene proxy temperature at that location. Coarse temporal resolution of the Holocene data, $\approx 1,000$ years, may mask brief warmer excursions, but cores with higher resolution (29) suggest that peak Holocene WEP SSTs were not more than $\approx 1^{\circ} \mathrm{C}$ warmer than in the late Holocene, before modern warming. It seems safe to assume that the SST will not decline this century, given continued increases of GHGs, so in a practical sense the WEP temperature is at or near its highest level in the Holocene. Fig. 5, including WEP data for the past 1.35 million years, shows that the current WEP SST is within $\approx 1^{\circ} \mathrm{C}$ of the warmest interglacials in that period.

The Tropical Pacific is a primary driver of the global atmosphere and ocean. The tropical Pacific atmosphere-ocean system is the main source of heat transported by both the Pacific and Atlantic Oceans (2). Heat and water vapor fluxes to the atmosphere in the Pacific also have a profound effect on the global atmosphere, as demonstrated by El Niño Southern Oscillation climate variations. As a result, warming of the Pacific has worldwide repercussions. Even distant local effects, such as thinning of ice shelves, are affected on decade-to-century time scales by subtropical Pacific waters that are subducted and mixed with Antarctic Intermediate Water and thus with the Antarctic Circumpolar Current.

The WEP exhibits little seasonal or interannual variability of SST, typically $<1^{\circ} \mathrm{C}$, so its temperature changes are likely to reflect large scale processes, such as GHG warming, as opposed to small scale processes, such as local upwelling. Thus, record Holocene WEP temperature suggests that global temperature may also be at its highest level. Correlation of local and global temperature change for 1880-2005 (Fig. 9, which is published as supporting information on the PNAS web site) confirms strong positive correlation of global and WEP temperatures, and an even stronger correlation of global and Indian Ocean temperatures.

The Indian Ocean, due to rapid warming in the past 3-4 decades, is now warmer than at any time in the Holocene, independent of any plausible shift of the modern temperature scale relative to the paleoclimate data (Fig. 4C). In contrast, the EEP (Fig. 4B) and perhaps Central Antarctica (Vostok, Fig. 4D) warmed less in the past century and are probably cooler than their Holocene peak values. However, as shown in Figs. $1 B$ and $3 A$, those are exceptional regions. Most of the world and the global mean have warmed as much as the WEP and Indian Oceans. We infer that global temperature today is probably at or near its highest level in the Holocene.

Fig. 5 shows that recent warming of the WEP has brought its temperature within $<1^{\circ} \mathrm{C}$ of its maximum in the past million years. There is strong evidence that the WEP SST during the penultimate interglacial period, marine isotope stage (MIS) 5e, exceeded the WEP SST in the Holocene by $1-2^{\circ} \mathrm{C}(30,31)$. This evidence is consistent with data in Figs. 4 and 5 and with our conclusion that the Earth is now within $\approx 1^{\circ} \mathrm{C}$ of its maximum temperature in the past million years, because recent warming has lifted the current temperature out of the prior Holocene range.

Western Equatorial Pacific SST $\left(0.3^{\circ} \mathrm{N}, 159.4^{\circ} \mathrm{E}\right): 1.35$ Million Years

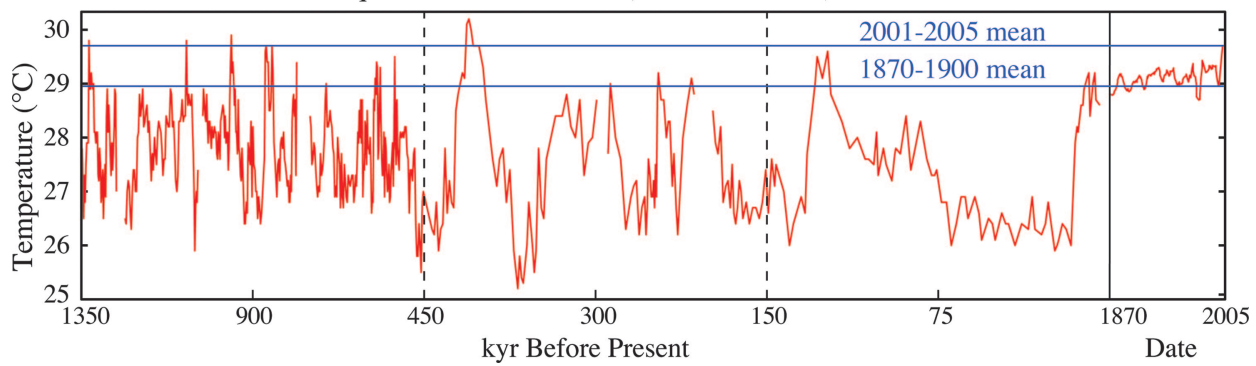

Fig. 5. Modern sea surface temperatures $(5,6)$ in the WEP compared with paleoclimate proxy data (28). Modern data are the 5-year running mean, while the paleoclimate data has a resolution of the order of 1,000 years. 
Criteria for Dangerous Warming. The United Nations Framework Convention on Climate Change (www.unfccc.int) has the objective "to achieve stabilization of GHG concentrations" at a level preventing "dangerous anthropogenic interference" (DAI) with climate, but climate change constituting DAI is undefined. We suggest that global temperature is a useful metric to assess proximity to DAI, because, with knowledge of the Earth's history, global temperature can be related to principal dangers that the Earth faces.

We propose that two foci in defining DAI should be sea level and extinction of species, because of their potential tragic consequences and practical irreversibility on human time scales. In considering these topics, we find it useful to contrast two distinct scenarios abbreviated as "business-as-usual" (BAU) and the "alternative scenario" (AS).

BAU has growth of climate forcings as in intermediate or strong Intergovernmental Panel on Climate Change scenarios, such as $\mathrm{A} 1 \mathrm{~B}$ or $\mathrm{A} 2$ (10). $\mathrm{CO}_{2}$ emissions in BAU scenarios continue to grow at $\approx 2 \%$ per year in the first half of this century, and non- $\mathrm{CO}_{2}$ positive forcings such as $\mathrm{CH}_{4}, \mathrm{~N}_{2} \mathrm{O}, \mathrm{O}_{3}$, and black carbon (BC) aerosols also continue to grow (10). BAU, with nominal climate sensitivity $\left(3 \pm 1^{\circ} \mathrm{C}\right.$ for doubled $\mathrm{CO}_{2}$ ), yields global warming (above year 2000 level) of at least $2-3^{\circ} \mathrm{C}$ by $2100(10,17)$.

AS has declining $\mathrm{CO}_{2}$ emissions and an absolute decrease of non- $\mathrm{CO}_{2}$ climate forcings, chosen such that, with nominal climate sensitivity, global warming (above year 2000) remains $<1^{\circ} \mathrm{C}$. For example, one specific combination of forcings has $\mathrm{CO}_{2}$ peaking at $475 \mathrm{ppm}$ in 2100 and a decrease of $\mathrm{CH}_{4}, \mathrm{O}_{3}$, and $\mathrm{BC}$ sufficient to balance positive forcing from increase of $\mathrm{N}_{2} \mathrm{O}$ and decrease of sulfate aerosols. If $\mathrm{CH}_{4}, \mathrm{O}_{3}$, and $\mathrm{BC}$ do not decrease, the $\mathrm{CO}_{2}$ cap in AS must be lower.

Sea level implications of BAU and AS scenarios can be considered in two parts: equilibrium (long-term) sea level change and ice sheet response time. Global warming $<1^{\circ} \mathrm{C}$ in AS keeps temperatures near the peak of the warmest interglacial periods of the past million years. Sea level may have been a few meters higher than today in some of those periods (10). In contrast, sea level was 25-35 $\mathrm{m}$ higher the last time that the Earth was $2-3^{\circ} \mathrm{C}$ warmer than today, i.e., during the Middle Pliocene about three million years ago (32).

Ice sheet response time can be investigated from paleoclimate evidence, but inferences are limited by imprecise dating of climate and sea level changes and by the slow pace of weak paleoclimate forcings compared with stronger rapidly increasing human-made forcings. Sea level rise lagged tropical temperature by a few thousand years in some cases (28), but in others, such as Meltwater Pulse $1 \mathrm{~A} \approx 14,000$ years ago (33), sea level rise and tropical temperature increase were nearly synchronous. Intergovernmental Panel on Climate Change (10) assumes negligible contribution to 2100 sea level change from loss of Greenland and Antarctic ice, but that conclusion is implausible $(17,34)$. BAU warming of $2-3^{\circ} \mathrm{C}$ would bathe most of Greenland and West Antarctic in melt-water during lengthened melt seasons. Multiple positive feedbacks, including reduced surface albedo, loss of buttressing ice shelves, dynamical response of ice streams to increased melt-water, and lowered ice surface altitude would assure a large fraction of the equilibrium ice sheet response within a few centuries, at most (34).

Sea level rise could be substantial even in the $\mathrm{AS}, \approx 1 \mathrm{~m}$ per century, and cause problems for humanity due to high population in coastal areas (10). However, AS problems would be dwarfed by the disastrous BAU, which could yield sea level rise of several meters per century with eventual rise of tens of meters, enough to transform global coastlines.

Extinction of animal and plant species presents a picture analogous to that for sea level. Extinctions are already occurring as a result of various stresses, mostly human-made, including climate change (35). Plant and animal distributions are a reflection of the regional climates to which they are adapted. Thus, plants and animals attempt to migrate in response to climate change, but their
Poleward Migration Rate of Isotherms ( $\mathrm{km} /$ decade)
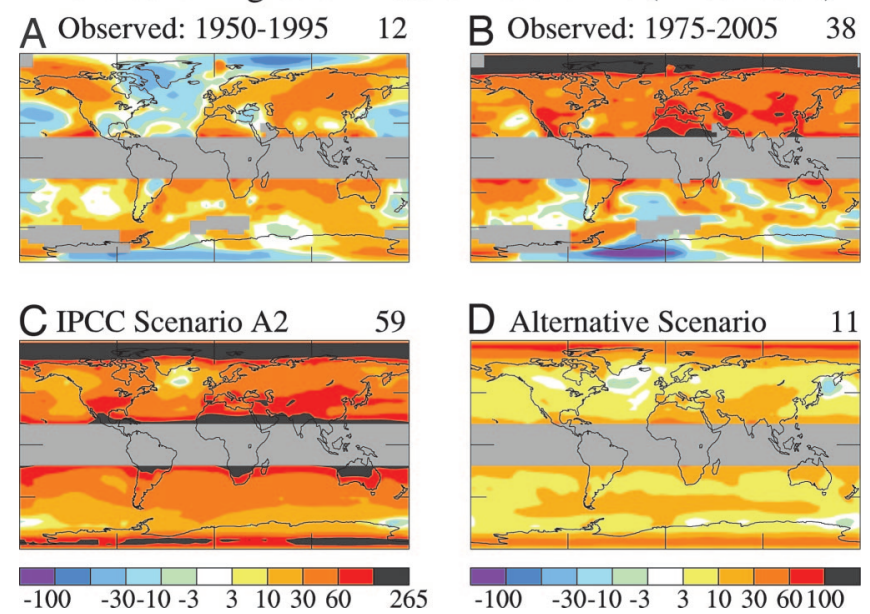

Fig. 6. Poleward migration rate of isotherms in surface observations ( $A$ and $B$ ) and in climate model simulations (17) for 2000-2100 for Intergovernmental Panel on Climate Change scenario A2 (10) and an alternative scenario of forcings that keeps global warming after 2000 less than $1^{\circ} \mathrm{C}(17)(C$ and $D)$. Numbers in upper right are global means excluding the tropical band.

paths may be blocked by human-constructed obstacles or natural barriers such as coastlines.

A study of 1,700 biological species (36) found poleward migration of $6 \mathrm{~km}$ per decade and vertical migration in alpine regions of $6 \mathrm{~m}$ per decade in the second half of the 20th century, within a factor of two of the average poleward migration rate of surface isotherms (Fig. 6A) during 1950-1995. More rapid warming in 1975-2005 yields an average isotherm migration rate of $40 \mathrm{~km}$ per decade in the Northern Hemisphere (Fig. 6B), exceeding known paleoclimate rates of change. Some species are less mobile than others, and ecosystems involve interactions among species, so such rates of climate change, along with habitat loss and fragmentation, new invasive species, and other stresses are expected to have severe impact on species survival (37).

The total distance of isotherm migration, as well as migration rate, affects species survival. Extinction is likely if the migration distance exceeds the size of the natural habitat or remaining habitat fragment. Fig. 6 shows that the 21st century migration distance for a BAU scenario $(\approx 600 \mathrm{~km})$ greatly exceeds the average migration distance for the AS $(\approx 100 \mathrm{~km})$.

It has been estimated (38) that a BAU global warming of $3^{\circ} \mathrm{C}$ over the 21 st century could eliminate a majority $(\approx 60 \%)$ of species on the planet. That projection is not inconsistent with mid-century BAU effects in another study (37) or scenario sensitivity of stress effects (35). Moreover, in the Earth's history several mass extinctions of $50-90 \%$ of species have accompanied global temperature changes of $\approx 5^{\circ} \mathrm{C}(39)$.

We infer that even AS climate change, which would slow warming to $<0.1^{\circ} \mathrm{C}$ per decade over the century, would contribute to species loss that is already occurring due to a variety of stresses. However, species loss under BAU has the potential to be truly disastrous, conceivably with a majority of today's plants and animals headed toward extermination.

\section{Discussion}

The pattern of global warming (Fig. $1 B$ ) has assumed expected characteristics, with high latitude amplification and larger warming over land than over ocean, as GHGs have become the dominant climate forcing in recent decades. This pattern results mainly from the ice-snow albedo feedback and the response times of ocean and land. 
In assessing the level of global warming that constitutes DAI, we must bear in mind that estimated climate sensitivity of $3 \pm 1^{\circ} \mathrm{C}$ for doubled $\mathrm{CO}_{2}$, based mainly on paleoclimate data but consistent with models, refers to a case in which sea ice, snow, water vapor, and clouds are included as feedbacks, but ice sheet area, vegetation cover, and non- $\mathrm{H}_{2} \mathrm{O}$ GHGs are treated as forcings or fixed boundary conditions. On long time scales, and as the present global warming increases, these latter quantities can change and thus they need to be included as feedbacks. Indeed, climate becomes very sensitive on the ice-age time scale, as feedbacks, specifically ice sheet area and GHGs, account for practically the entire global temperature change (17).

Vegetation cover is already expanding poleward in the Northern Hemisphere causing a positive climate feedback (42). Global warming could result in release of large amounts of GHGs, e.g., from melting permafrost or destabilized methane clathrates on continental shelves (43). Some of the largest warmings in the Earth's history and mass extinctions may be associated with such GHG releases $(39,43)$. Although such disastrous GHG releases may require many centuries, our ignorance of GHG climate feedbacks demands caution in estimating requirements to avoid DAI.

The AS is based on the rationale that positive feedbacks such as GHG release, as well as sea level rise, will be limited if global temperature stays within the range of recent interglacial periods. Ice core data reveal a positive GHG feedback, GHG changes lagging temperature change, but the feedback magnitude is moderate $\left(\mathrm{CO}_{2},+20 \mathrm{ppm}\right.$ per ${ }^{\circ} \mathrm{C} ; \mathrm{CH}_{4},+50$ ppb per $\left.{ }^{\circ} \mathrm{C}\right)$ even if the entire observed gas change is a feedback (44). However, paleo data do not constrain the magnitude of feedbacks under BAU warming, which is far outside the range of interglacial temperatures.

Such feedbacks enhance the dichotomy between AS and BAU scenarios. If global warming is not limited to $<1^{\circ} \mathrm{C}$, feedbacks may

1. Hansen J, Sato M, Ruedy R, Nazarenko L, Lacis A, Schmidt GA, Russell G, Aleinov I, Bauer M, Bell N, et al. (September 28, 2005) J Geophys Res 110:10.1029/2005JD005776.

2. Pierrehumbert RT (2000) Proc Natl Acad Sci USA 97:1355-1358.

3. Lea DW (2004) J Climate 17:2170-2179.

4. Hansen J, Ruedy R, Sato M, Imhoff M, Lawrence W, Easterling D, Peterson T, Karl T (2001) J Geophys Res 106:23947-23963.

5. Reynolds RW, Smith TM (1994) J Clim 7:929-948.

6. Rayner N, Parker D, Horton E, Folland C, Alexander L, Rowell D, Kent E, Kaplan, A (July 17, 2003) J Geophys Res 108:10.1029/2002JD002670.

7. Hansen J, Lebedeff S (1987) J Geophys Res 92:13345-13372.

8. Hansen J, Ruedy R, Glascoe J, Sato M (1999) J Geophys Res 104:30997-31022.

9. Comiso JC (2006) Weather 61:70-76.

10. Intergovernmental Panel on Climate Change (2001) Climate Change 2001: The Scientific Basis, eds. Houghton JT, Ding Y, Griggs DJ, Noguer M, van der Linden PJ, Dai X, Maskell K, Johnson CA (Cambridge Univ Press, Cambridge, UK).

11. Manabe S, Wetherald RT (1975) J Atmos Sci 32:3-15.

12. Hansen J, Fung I, Lacis A, Rind D, Lebedeff S, Ruedy R, Russell G, Stone P (1988) J Geophys Res 93:9341-9364.

13. US Senate Commission on Energy and Natural Resources (1988) Greenhouse Effect and Global Climate Change (Govt Printing Office, Washington, DC).

14. Crichton M (2004) State of Fear (Harper Collins, New York).

15. U.S. Senate Commission on Environment \& Public Works (2005) The Role of Science in Environmental Policy-Making (Govt Printing Office, Washington, DC).

16. Barnes F (2006) Rebel in Chief: Inside the Bold and Controversial Presidency of George W. Bush (Crown Forum, New York)

17. Hansen J (2005) Am Geophys Union U23D-01.

18. Michaels PJ (2000) Soc Epistemol 14:131-180.

19. Fedorov AV, Philander SG (2000) Science 288:1997-2002.

20. Cane MA (2005) Earth Plan Sci Lett 230:227-240.

21. Bjerknes J (1969) Mon Wea Rev 97:163-172.

22. Collins M (2005) Clim Dyn 24:89-104. add to BAU emissions, making a "different planet" (17), including eventual ice-free Arctic, almost inevitable. The AS requires concerted efforts to both slow $\mathrm{CO}_{2}$ emissions and reduce atmospheric amounts of $\mathrm{CH}_{4}, \mathrm{O}_{3}$, and $\mathrm{BC}(17,34)$. Achievement of the AS should limit positive climate feedbacks. However, continuation of BAU growth of $\mathrm{CO}_{2}$ emissions ( $\approx 2 \%$ per year) through 2015 yields $+35 \% \mathrm{CO}_{2}$ emissions relative to $2000 \mathrm{CO}_{2}$ emissions and $+40 \%$ $\mathrm{CO}_{2}$ emissions relative to AS $2015 \mathrm{CO}_{2}$ emissions. Given the long life of $\mathrm{CO}_{2}$ and the impact of feedbacks on the plausibility of $\mathrm{CH}_{4}$ reductions, another decade of BAU emissions probably makes the AS infeasible.

Inference of imminent dangerous climate change may stimulate discussion of "engineering fixes" to reduce global warming $(45,46)$. The notion of such a "fix" is itself dangerous if it diminishes efforts to reduce $\mathrm{CO}_{2}$ emissions, yet it also would be irresponsible not to consider all ways to minimize climate change. Considering the evidence that aerosol effects on clouds cause a large negative forcing (10), we suggest that seeding of clouds by ships plying selected ocean regions deserves investigation. However, given that a large portion of human-made $\mathrm{CO}_{2}$ will remain in the air for many centuries, sensible policies must focus on devising energy strategies that greatly reduce $\mathrm{CO}_{2}$ emissions.

We thank Ralph Cicerone for reviewing our submitted paper; Mark Bowen, Mark Cane, Adam Chambers, Bob Grumbine, Mickey Glantz, Isaac Held, Bruce Johansen, Margaret Kneller, Chuck Kutscher, Ehrhard Raschke, Joe Romm, Bill Ruddiman, Gus Speth, Harry van Loon, Gabriel Vecchi, Michael Wright, and Steve Zebiac for comments on a draft manuscript; Darnell Cain for technical assistance; and National Aeronautics and Space Administration Earth Science managers Jack Kaye, Don Anderson, and Eric Lindstrom and Hal Harvey of the Hewlett Foundation for research support.

23. Ravelo AC, Andreasen DH, Lyle M, Olivarez Lyle A, Wara MW (2004) Nature 429:263-267.

24. Held IM, Soden BJ (2006) J Clim 19: in press.

25. Knutson T, Manabe S (1995) J Clim 8:2181-2199.

26. Vecchi G, Soden BJ, Wittenberg AT, Held IM, Leetmaa A, Harrison, MJ (May 4, 2006) Nature, 10.1038/nature04744.

27. Emanuel K (1987) Nature 326:483-485.

28. Medina-Elizade M, Lea DW (2005) Science 310:1009-1012.

29. Stott L, Cannariato K, Thunell R, Haug GH, Koutavas A, Lund S (2004) Nature 431:56-59.

30. Lea DW, Pak DK, Spero HJ (2000) Science 289:1719-1724.

31. Lea DW, Pak DK, Belanger CL, Spero HJ, Hall AM, Shackleton NJ (2006) $Q$ Sci Rev 25:1152-1167.

32. Dowsett H, Thompson R, Barron J, Cronin T, Fleming F, Ishman S, Poore R, Willard D, Holtz T (1994) Global Plan Change 9:169-195.

33. Kienast M, Hanebuth TJJ, Pelejero C, Steinke S (2003) Geology 31:67-70

34. Hansen J (2005) Clim Change 68:269-279.

35. Hare W (2003) Assessment of Knowledge on Impacts of Climate Change (German Advisory Council on Global Change, Berlin).

36. Parmesan C, Yohe G (2003) Nature 421:37-42.

37. Thomas CD, Cameron A, Green RE, Bakkenes M, Beaumont LJ, Collingham YC, Erasmus BFN, Siqueira MF, Grainger A, Hannah L, et al. (2004) Nature 427:145-148

38. Flannery T (2005) The Weather Makers (Atlantic Monthly, New York).

39. Benton MJ (2003) When Life Nearly Died (Thames \& Hudson, London).

40. Saraswat R, Nigam R, Weldeab S, Mackensen A, Naidu PD (December 17, 2005) Geophys Res Lett 32:10.1029/2005GL024093.

41. Vimeux F, Cuffey KM, Jouzel J (2002) Earth Planet Sci Lett 203:829-843.

42. Chapin FS, Sturm M, Serreze MC, McFadden JP, Key JR, Lloyd AH, McGuire AD, Rupp TS, Lynch AH, Schimel JP, et al. (2005) Science 310:657-660.

43. Archer D (2006) Rev Geophys, in press.

44. Hansen J, Sato M (2004) Proc Natl Acad Sci USA 101:16109-16114.

45. Cicerone RJ (2006) Clim Change 77:221-226.

46. Crutzen PJ (2006) Clim Change 77:211-219. 